\title{
РИМСКОЕ ЧАСТНОЕ ПРАВО КАК ФУНДАМЕНТАЛЬНЫЙ ИНСТИТУТ ИСТОРИЧЕСКОГО СТАНОВЛЕНИЯ И РАЗВИТИЯ ДОГОВОРА ХРАНЕНИЯ
}

\author{
(c) 2020 Умархаджиева Седа Руслановна \\ старший преподаватель \\ Чеченский государственный университет, Россия, Грозный \\ Email: seda.umarkhadzhieva@mail.ru
}

В научной работе приводится историческая справка становления и развития договора хранения в римском частном праве как фундаментального института российского гражданского права. Анализируются нормативные правовые акты периода римской государственности, послужившие побудительным мотивом становления института хранения.

Ключевые слова: договор складского хранения, становление и развитие, римское частное право, институт хранения, ознакомление, просвещение.

Анализирование и регламентация научной основы любого юридического института современной правовой системы Российской Федерации в историческом контексте является ключевым аспектом в становлении целостной юридической науки.

Договор хранения со всеми его разновидностями отображается существенным наравне с основными видами договоров гражданскоправового характера. Как и всякий иной вид гражданско-правового института, за долголетнюю многовековую историю развития, совершенствования и детальной регламентации, договор хранения синтезировал, как представляется, довольно большие изменения.

В этой связи, обозначенные корректировки отображали динамичный прогрессивный характер, выражающийся в плавном переходе от обыденной нормы гражданско-правового характера, до кодификационной, а кроме того, исключение скоротечности изменений договора хранения и его разновидностей.

При выделении этапов развития и становления договора хранения и его разновидностей, в хронологическом этапном порядке, отображается картина, которая состоит из следующих исторических этапов детальной регламентации:

- этап формирования и становления договора хранения и присущих ему классификаций в римском частном праве;

- этап формирования и становления договора хранения и присущих ему классификаций в гражданском праве Древнерусского государства в начале княжества;

- этап формирования и становления дого- вора хранения и присущих ему классификаций в гражданском праве средневековой Руси в период исторического царизма;

- этап формирования и становления договора хранения и присущих ему классификаций в историческую бытность Российской империи в процессе становления европейского гражданского права;

- этап формирования и становления договора хранения и присущих ему классификаций в Советский период государственности в процессе становления Советского гражданского права;

- этап формирования и становления договора хранения и присущих ему классификаций, после принятия Гражданского кодекса Российской Советской Федеративной Социалистической Республики 1964 года, с переходом к системе развитого социализма;

- этап формирования и становления договора хранения и присущих ему классификаций в настоящий этап научной регламентации гражданского законодательства Российской Федерации [1].

В обозначенной научной работе будет приведена историческая справка договору хранения, существовавшему в римском обществе, и нашедшему свое отражение в римском частном праве.

На этапе формирования и развития римского частного права институт хранения в целом характеризовался как гражданский договор контрактной формы, по которому исполнительное лицо, получившее от иного уполномоченного лица определенную вещь имущественного характера, обязывалось в императивной форме 
на безвозмездной основе в течение определенного срока и до момента востребования вещи хранить и по окончанию срока хранения в целости и сохранности возвратить поклажедателю (уполномоченному лицу) вещь в надлежащем состоянии [2].

Данное основополагающее правило становления договора хранения как независимого института частного права, является принципиальной составляющей существования договора хранения и института поклажи также и в настоящее время.

Римское частное право раскрывало следующие императивные отличительные признаки договора хранения:

- договор хранения - является реальным контрактом, по которому гражданско-правовое обязательство возникает посредством передачи вещи поклажедателем хранителю с возникновением определенных гражданско-правовых обязательств у хранителя и поклажедателя по договору хранения;

- поклажедателем, передающим индивидуально-определенную вещь имущественного характера, может быть любое заинтересованное уполномоченное лицо, даже если оно и не является собственником данного имущества, представленного в натуральной форме, кроме самого хранителя вещи [3]. В этой связи, исходя из детального рассмотрения данной императивной нормы, можно сделать вывод о том, что даже «вор», похитивший вещь, диспозитивно имел личную заинтересованность в хранении украденной вещи, вместе с тем, необходимо акцентировать внимание и на том, что в процессе совершенствования и становления жизнедеятельности общества, указанные нормы понесли существенные отличительные изменения в пользу добросовестного собственника хранимого имущества имеющего ценовой эквивалент;

- по договору хранения, хранителю доверялись на хранение только вещи индивидуальноопределенного характера, наделенные родовыми признаками индивидуально-определенного характера, которые в свою очередь, имели материально-имущественный характер и подлежали гражданско-правовому обороту в соответствии с общепринятыми правилами гражданского оборота;

- основным направлением и сущностным свойством (целью) хранения вещи - является хранение ее хранителем, у которого не было правомочия использования переданной на хранение индивидуально-определенной вещи имеющей ценовой эквивалент, а обладания правомочия хранения имущества лишь держателем вещи [4], по окончанию срока хранения вещи которой обязан был вернуть хранимую вещь поклажедателю по основополагающим правилам договора хранения.

Более того, наравне с указанными выше признаками, на базовом этапе формирования и становления договора хранения и присущих ему классификаций, имели место и иные, имеющие второстепенное значение для регулирования общественных отношений, возникающих между субъектами договорных отношений, и заключались они в нижеследующем:

- индивидуально-определенная вещь, имеющая ценовой эквивалент, могла быть передана на хранение по договору хранения до обратного требования или на определенный срок. Обозначение срока в договоре хранения отражалось лишь второстепенным условием [5], однако соблюдение существенного условия о сроке хранения индивидуально-определенной вещи, имеющей ценовой эквивалент, являлось значительной составляющей нарушающего требования условий хранения вещи хранителем;

- по истечению установленного срока хранения вещи, на основании целей договора хранения индивидуально-определенная вещь должна была быть возвращена собственнику вещи с сохранением устойчивых свойств вещи, имевших место в момент передачи на хранение поклажедателем хранителю [6];

- договор хранения вещи индивидуальноопределенными характеристиками носил безвозмездную форму и заключался на дружественных доверительных отношениях между сторонами (поклажедателем и хранителем) [7].

С учетом изложенного, отображается природа договора хранения, который на начальном этапе формирования и детализации складывался на доверительных отношениях.

Однако, несмотря на доверительные отношения между субъектами договора хранения необходимо отметить, что хранитель вещи, не имел право пользоваться ею в случае нарушения данного запрета и его действия считались незаконным пользованием которые квалифицировались как кража.

Важным условием также являлось и то, что хранитель обязан был осуществлять хранение 
вещью лично, то есть исполнять договор непосредственно, без вовлечения в осуществление других лиц. Необходимость данной императивной нормы заключалось в том, что отношения доверительного характера складывались исключительно между поклажедателем и хранителем и передача вещи хранителем иному лицу проявлялось нежелательным жестом и поведением в римском обществе [8].

Также не могли быть вознесены и переданы на другое лицо обязанности при хранении вещи.

В историческом контексте становления римское частное право отображало несколько классификаций договора хранения, так, в свою очередь, выделялись горестная или несчастная поклажа, по которой собственник передаваемого на хранение имущества передавал на хранение индивидуально-определенную вещь, обладающую родовыми признаками в чрезвычайной ситуации природного характера и техногенного характера. Для иллюстрации можно привести следующие виды катастроф природного и техногенного характера, например - землетрясение, наводнение, вооруженные конфликты, пожары и иные возможные случаи природных и техногенных катастроф. В свою очередь и на поклажедержателе вещи, в обозначенных видах хранения имущества, накладывалась повышенная мера ответственности, оправдываемая отсутствием возможности при перечисленных обстоятельствах, возможностью нахождения собственником имущества другого поклажедер- жателя.

Особую классификацию договора хранения индивидуально-определенной вещи и вещи, имеющей родовые признаки, представляла необычная поклажа. Обозначенный вид договора хранения индивидуально-определенной вещи и вещи, имеющей родовые признаки, выражался в том, что на хранение могли быть переданы не только вещи, наделенные индивидуальноопределенными признаками, но также и вещи, определенные родовыми признаками, но имеющие материальную составляющую гражданскоправового оборота, обладающего ценовым эквивалентом стоимости. Например, могли быть переданы деньги и иные ценные предметы, исходя из чего, данную разновидность хранения в римском частном праве называли необычной поклажей.

Наряду с вышеперечисленными видами поклажи, в римском частно-правовом пространстве существовал и такой вид договора хранения, как секвестр. Данный вид договора хранения характеризовался как передача на хранение вещи нескольким лицам на индивидуальноопределенных условиях [9].

Исходя из всего вышесказанного, можно сделать вывод о том, что основной базис для дальнейшего развития и совершенствования договора хранения как цельного и сформированного института гражданского права, был детализирован и синтезирован именно римским частным правом.

\section{Библиографический список}

1. Римское частное право: Учебник/ Под. ред. И.Б. Новицкого, И.С. Перетерского. М., 2013. - С. 410-411.

2. Подопригова А.А. Основы римского гражданского права: Учебное пособие. Киев, 2014.- С. 213.

3. Римское частное право: Учебник/ Под. ред. И.Б. Новицкого, И.С. Перетерского. М., 2013.- С. 412-413.

4. Еремичев И., Новокшонова Н., И при хранение главное договориться. История вопроса // Закон. 2001. № 3.C. 17.

5. Римское частное право: Учебник/ Под. ред. И.Б. Новицкого, И.С. Перетерского. М., 2013. - С. 413.

6. Римское частное право: Учебник/ Под. ред. И.Б. Новицкого, И.С. Перетерского. М., 2013. - С. 413.

7. Еремичев И., Новокшонова Н., И при хранение главное договориться. История вопроса // Закон. 2001. № 3.C. 12.

8. Римское частное право: Учебник/ Под. ред. И.Б. Новицкого, И.С. Перетерского. М., 2013.- С. 416.

9. Законы 12 таблиц // Памятники римского гражданского права: Законы 12 таблиц, Институции Гая, Дигесты Юстиниана. М., 2012.- С. 12. 